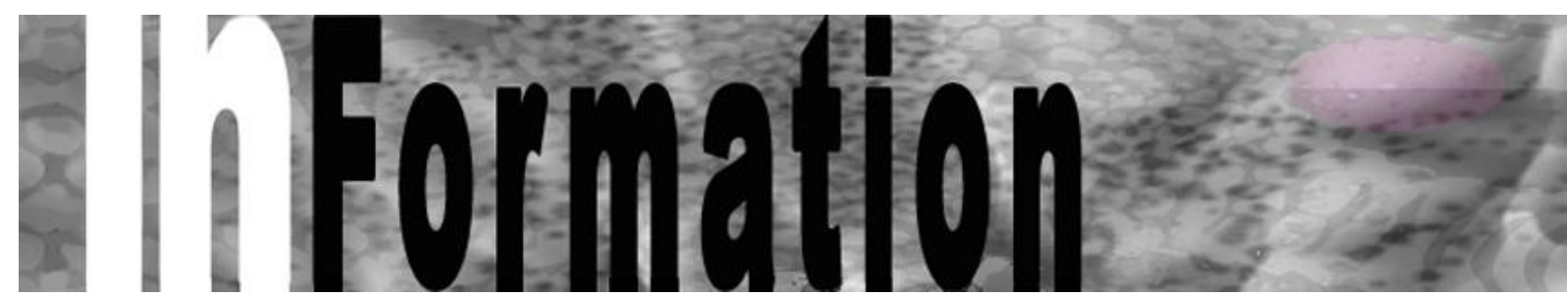

Nordic Journal of Art and Research

ISSN: 1893-2479

$\underline{\text { www.artandresearch.info }}$

\title{
Pop Music for Kids: Sonic Markers as Narrative Strategies in Children's Music
}

\author{
Eirik Askerøi ${ }^{1}$ \\ Inland Norway University of Applied Sciences
}

\begin{abstract}
Whilst the creative handling of recording technology has played a major role in the development of popular music, there has been little research into the role of production in music promoted explicitly for a child audience. The term "tween" is most often applied to describe children just before they become teens, referring to children aged 9-12 years. In more recent years, however, the tween category has come to comprise children as young as 4 and up to 15 years of age. Based on the premise that there is a growing tendency for children to be "youthified" at a far younger age than occurred previously, I am keen to investigate the extent to which music plays a part in this process. Through close readings of three songs from different eras in the history of children's music, I will explore the role of sonic markers as narrative strategies in children's music. The overall aim is to discuss the extent to which the relationships between lyrical content, vocal performance, and production aesthetics may play a role in the youthification of child performers and audiences.
\end{abstract}

Keywords: sonic markers, children's music, tweens, youthification, popular music

\section{Introduction}

Throughout recording history, the sonic effect of different technologies and instruments has left a lasting impression on recordings, suggesting an almost intrinsic relationship between sound and period. In addition, producers and engineers, especially within the realm of popular music, have taken compositional advantage of this relationship, constructing what I have elsewhere labeled sonic markers, or "musical codes that have been historically grounded through a specific context, and that, through their appropriation, serve a range of narrative purposes in recorded music" (Askerøi, 2013, p.17). In this article I will examine the extent to which sonic markers may serve as narrative strategies in the increasing "youthification" of children, both for protagonists and consumers.

\footnotetext{
${ }^{1}$ Inland Norway University of Applied Sciences. E-mail: eirik.askeroi@inn.no.
} 
Situated within the field of popular musicology, this article navigates methodologically between overarching contextual perspectives and close readings of selected musical examples. The purpose of choosing close readings as a methodological approach is to add a detailed, musicological dimension to the broader, historiographical perspective presented elsewhere in this volume (see Dyndahl \& Vestad, 2017). Dyndahl and Vestad suggests three periods in the development of recorded music for children: The period between 1945 and 1959 constitutes the early years, and it is during this period that recorded music was promoted directly to a child audience in Norway. From 1960 to 1985, the formative years, the dedicated children's culture was shaped and developed. Then, from 1986 to the present - a period labeled continuity, consolidation, and change - recorded music for children played an increasing role in popular culture's marketing strategies, recognizing children's culture as an independent field with significant commercial potential.

Operating mainly within the context of the two latter periods, I shall examine the role of sonic markers as narrative strategies in children's music on two levels:

1. The fictional narrative: when sonic markers function as strategies for underlining and supporting the storytelling in songs related to narrations for children through theatre, film, or television.

2. The narrative of the "real": when sonic markers function as strategies for authenticating child personae in order to bridge the gap between music for children and music for adolescents.

As examples of these strategies, I have chosen three songs that are well known to child audiences in Norway and can serve as detailed spot checks of the two latter time periods. The first example is Bengt Hallberg and Astrid Lindgren's song "Ge mej mera köttbullar" [Give me more meatballs] as performed by Madicken and her little sister Lisabet from the Swedish TV series Madicken (Lindgren, 2003). ${ }^{2}$ The second example is "Pinkys sang" [Pinky's song] (Formoe, 2006), from the enormously popular children's series Kaptein Sabeltann. Third, I have chosen Marcus and Martinus' song "Slalom," from their album $\mathrm{Hei}$ (2015). On the one hand, these examples vary greatly in terms of sonic output and time of production. On the other hand, they hold defined positions within the suggested framework for my readings. Settling on details in this context means identifying what Stan Hawkins has conceptualized as musical moments, which "warrant[s] for close attention to details rather than to the full breadth of the text in question" (Hawkins, 2009, p. 13).

\section{"Growing Older Younger": Toward a Youthification of Children's Music}

In the following section, I present some background for understanding child performers as agents in a gradual youthification of children's music. Theoretically, youthification is used in at least two ways. On the one hand, the term can be used to describe "the growing influx of young adults, those aged between 25 and 34, into higher density cities" (MacFarlan, 2015). In other words, it can be a form of social mobility associated specifically with a certain age group. On the other hand, youthification is also used to describe a form of escape from one's own generation into some form of "eternal" youth. This can take place either from a child's or adult's perspective. Robert Latham (2002), in his book Consuming Youth, summed up this perspective on youthification as follows:

\footnotetext{
${ }^{2}$ Many recordings of this song exist. In this article, I refer to the recording appearing on the album Madicken på Junibacken (2003), featuring Joanna Liljendahl as Madicken and Liv Alsterlund as Lisabet. This version of the song was featured in the movie Madicken på Junibacken (1980) and originally released on the LP Madicken (1979).
} 
a "state of arrested development" that "encourages everyone, including adults and young children, to think and act like adolescents." Thus, from the perspective of these critics, the consumer-whether adult, adolescent or child - is, like the vampire, trapped in a stasis of perceptual youth, and ongoing Teenage Tyranny ... whose reign is as endless as the capacity of capitalism to generate ever-new, ever-youthful commodities. (p. 47)

For Latham, youthification describes a desire for eternal youth - a desire propelled by commercial products that includes young children as well as adult. In this sense, it could be regarded in close relation to a gradually expanding "tween" category, earlier associated with an age group from 9 to 12 years of age. According to Tyler Bickford (2012), this category now ranges from 4 to 15 years of age as a result of growing attention from the music industry:

With regard to music, at one time children could clearly be seen to move through age graded "tastes" . . but now brands like Kidz Bop and Disney market the same music to children as young as four and as old as fifteen (or even older). (p. 419)

According to Bickford, music that is targeted directly at a tween audience is a rapidly expanding vein of the music industry, capitalizing heavily on the tendency that children are "growing older younger" (Montgomery, as cited in Bickford, 2012, p. 419). It must be noted here that Bickford wrote from a US perspective, but the transfer value is still arguably present in a Scandinavian context.

For example, Bickford's argument would resonate well with Vestad's (2015a) observation that popand rock-like genres are increasingly encapsulating child performance and agency in Norway through shows such as Melodi Grand Prix Junior (MGP Junior). Based on Ruud's (1983) definition as music produced for and distributed to children, Vestad (2015a) showed how children's music has undergone drastic changes in both repertoire and focus during the last half of the twentieth and the beginning of the twenty-first century:

The music that was produced and distributed to children via radio toward the end of the 1940s and 1950s mainly consisted of older, traditional children's ditties and songs, educational songs for children, modeled on circle time in the kindergarten, classical music, and newly composed children's songs. (. . .) In the 2000s, MGP Junior has become popular with the oldest children in the kindergarten, especially among those who have elder siblings. This show is mainly dominated by pop- and rock-like genres, and the music is (at least partly) written and performed by the children themselves. (Vestad, 2015a, p. 56 [my translation])

From traditional children's songs, often with an educational agenda, there was a gradual development in the 1940s and 1950s toward a more pop- and rock-oriented generic discourse, often initiated by TV shows such as MGP Junior. The role of this show for children today should not be underestimated. In light of what Bickford (2012) and later Vestad (2015a) understood as an emerging childhood counterpublic in a growing "tween" music industry, I would argue that the question as to whether or not the use of musical sound as a compositional tool plays a role in children's music can be approached against the rapid changes that took place within the realm of recording history.

The role of the recorded medium, as Toynbee (2000) noted, had already transitioned from a documentation mode toward a projection mode during the 1960s. According to Toynbee, artists and bands such as The Beatles and The Beach Boys experienced increasing challenges in reproducing their recordings "live" as early as in the late 1960s. One reason was that, in this period, the music industry began to look seriously at the economic potential of recordings as an individual commodity. The challenges that musicians faced could therefore be traced to the increasing complexity of production. During the 1960s, the recorded medium developed from serving as the documentation of a performance into a projection of collaborative studio work. The recording, in other words, gradually became the 
original. ${ }^{3}$ The process of "pop-rockization," as described by Vestad (2015a) above and further discussed by Dyndahl and Vestad (2017), may therefore also be considered in relation to this development. If a documentation mode governed the recording industry in the 1940s and 1950s, this was also the case with music for children.

Alf Prøysen's early recordings provided an example of this. On the compilation album Original Proysen 4 (1993), which is a collection of his most famous children's songs, recorded between 1946 and 1957, the sound quality improved drastically from the first recordings of "Lillebror's Vise" and "Blåbærturen" to later recordings of songs such as "Soltrall." Since most of Prøysen's recordings are played live in a radio studio, the quality difference in the recording equipment is audible. In "Lillebror's Vise," for example, the roomy sound of the piano enhances the nasal quality of Prøysen's recorded voice, indicating the use of one microphone. In "Soltrall," Prøysen's voice sounds remarkably closer and has a much wider frequency spectrum. The balance between voice and acoustic guitar, with the latter figuring in the background, may indicate that this is also recorded with one microphone. Although the changes in the sound quality of these recordings took place over little more than 10 years, the recordings indicate that documenting a live performance still remained the goal of the recording. According to Tønnesen (2015), NRK did in fact have a goal of creating a sense of closeness between the program leader and his or her listeners. Inspired by Ruth Fenner's Australian concept Nursery on the Air from the late 1940s, Barnetimen for de minste represented a "direct form of address, based on new ideas about how the radio medium invites communication with the children" (Tønnesen, 2015, p. 93 [my translation]). As Vestad (2015b) further noted, when Prøysen asked the listeners to lay their hands on the radio, they were supposed to do so.

By contrast, in the 2000s, as a projection mode had been well established as the dominant recording ideal, a wide array of record production tools, from effects processing to beat programming, undoubtedly affected how music for children was produced. In her article "Det aller største mor vet om," Vestad (2015b) provided an illustrating example of the potential tension that arises in the meeting between two such ideals. Vestad described a mother's attempt to convey her own childhood experience with Prøysen's music to her five-year-old son. One of Vestad's points was the boy's reaction to the sound quality of the Prøysen recordings. His first reaction was to the noise, but he hastily turned this observation into an interpretation: "For him, the sound quality signals old music, but not necessarily in the positive sense of 'real' and 'authentic' qualities that his mother emphasizes" (Vestad 2015b, p. 44 [my translation]). Apart from the quality of the recording itself, which has undergone a digital remediation from old tapes in the radio broadcasting archives to the $\mathrm{CD}$, it is also interesting to note that the boy immediately characterized Prøysen as being old - a characterization mainly based on Prøysen's vocal performance and the musical environment through which this performance was conveyed. In short, although initially intended to mobilize a sense of closeness between Prøysen and his listeners, vocal performance and piano accompaniment become sonic markers in a narrative of distance for the little boy.

\section{Sonic Markers in Fictional Narratives}

So far, I have drawn some technologically founded lines in the development of an autonomous children's culture. Vestad's example with Prøysen strongly indicates that audible aspects of music can actually play a role, although quite unintendedly, in conveying a narrative to the listener. This indicates that

\footnotetext{
${ }^{3}$ As Toynbee also noted, the term "live" arose as a result of this process and appeared for the first time during the 1950s.
} 
aspects of performance and production would hold a narrative potential if used consciously in recorded music. To what extent, then, is this potential considered in music for children? In the following section, I take a closer look at lyrics, vocal performances, and aspects of production aesthetics in two musical examples, demonstrating how sonic markers help to convey a fictional narrative. Lyrics and vocal performance play an important role in most popular music, not least in music for children. I argue that what the characters and artists sing about, but also how they sing about it, affect the listening experience.

Madicken is a fictional character featured in a series of Astrid Lindgren's children's books, which have been adapted for film and television. Madicken grows up in a middle-class Swedish home with her little sister, Lisabet, in a small village during World War I. ${ }^{4}$ The two girls are faced with everyday problems such as getting a pea out of the other sister's nose, jumping off rooftops with an umbrella as a parachute, and sneaking out late at night looking for ghosts to discover whether they are psychic. According to biographer Vivi Edström (1997), there was one particular aspect that Lindgren highlighted for the first time in her books about Madicken, namely the class distinctions in Sweden at the time. This provides an interesting background for the song "Ge mej mera köttbullar," in which the two sisters address a theme that today would seem relevant to children of all ages: what to like and what not to like when it comes to food. The song's narrative is spun around three dishes: meatballs, pancakes, and fish pudding. As one might expect, the first two end up on the list of likes, whereas fish pudding is securely situated on Madicken and Lisabet's hate list:

Fiskpudding, fiskpudding, fiskpudding,

Ge mig inte fiskpudding,

Hemsk otäck fiskpudding

Ge mig inte fiskpudding,

Avskyvärd fiskpudding

Ge mig inte fiskpudding,

Jag hatar fiskpudding.

Ge mig inte fiskpudding,

Kom inte hit med nån fiskpudding

För då skriker jag: JAG VILL INTE HA!
Fish pudding, fish pudding, fish pudding,

Don't give me fish pudding,

Gross, revolting fish pudding

Don't give me fish pudding

Abominable fish pudding

Don't give me fish pudding

I hate fish pudding

Don't give me fish pudding

Don't come here with any fish pudding

Because then I'll scream: I DO NOT WANT IT!

The years after 1916 were characterized by industrial stagnation both in Norway and Sweden because of the effects of World War I (Bore, 2005). Thus, for an increasing number of people, it must have been quite a luxury to be able to choose the food one prefers and spurn the food one dislikes. Madicken and her family apparently had that luxury as a result of their father's position as a prominent newspaper

\footnotetext{
${ }^{4}$ It must be noted here that Sweden, like Norway and Denmark, was neutral during this war and thus not involved (at least directly) in the sense that was the case with several central European countries. News from the war, however, tended to make headlines in the newspaper of which the fictional Madicken's father was editor.
} 
editor. For her friend and neighbor Abbe Nilsson, the situation was quite the opposite — not least because of his father:

Daddy Nilsson, with his elevated floral language, is an alcoholic and a fraud who lies on his couch, dedicated to feeling "life within him," while his wife and his son Abbe struggle for their daily bread. (Edström, 1997, p. 69 [my translation])

These social dynamics are only briefly mentioned in the books and movies, and I am not suggesting they should be the focus when listening to "Ge mej mera köttbullar." At the same time, it could be argued that the song's appeal has to do with lyrics that children can relate to, delivered with an energy that is appealing in itself. For many children, an appealing contradiction could also appear in the depiction of apparently well-behaved, pretty children behaving badly by complaining about the food. In addition, this appeal is also underlined by the lightness and energy provided by the musical backdrop.

Allan F. Moore, in his book, Song Means (2012), made a useful distinction between persona and environment in recorded music, defining the environment by how it relates to the persona in different ways. According to Moore, "(T)he impact an environment can have on the persona can range from the significant to the trivial, as accompanimental textures, harmonies and forms serve both subtle and blatant functions" (p. 191). Taking Moore's concept of environment to a more detailed level, sonic markers provide a close reading of the sonic features of the songs in question. In short, sonic markers allow the reader to consider the potential effect of these sonic characteristics on the protagonist as well as on the meaning of the song in question. In "Ge mej mera köttbullar," the music would not appear to relate directly either to the context of the personae or to the theme of the lyrics. Built around a unison bass and guitar motif (Figure 1), and further accompanied by a minimalist drum arrangement, the environment in this song leaves a relatively open space for the vocal expression of the two girls to come through in the mix without much resistance. The dry sound of the electric guitar is significant here, as it could potentially evoke an early 1960s aesthetic, although the song was first released in 1979:

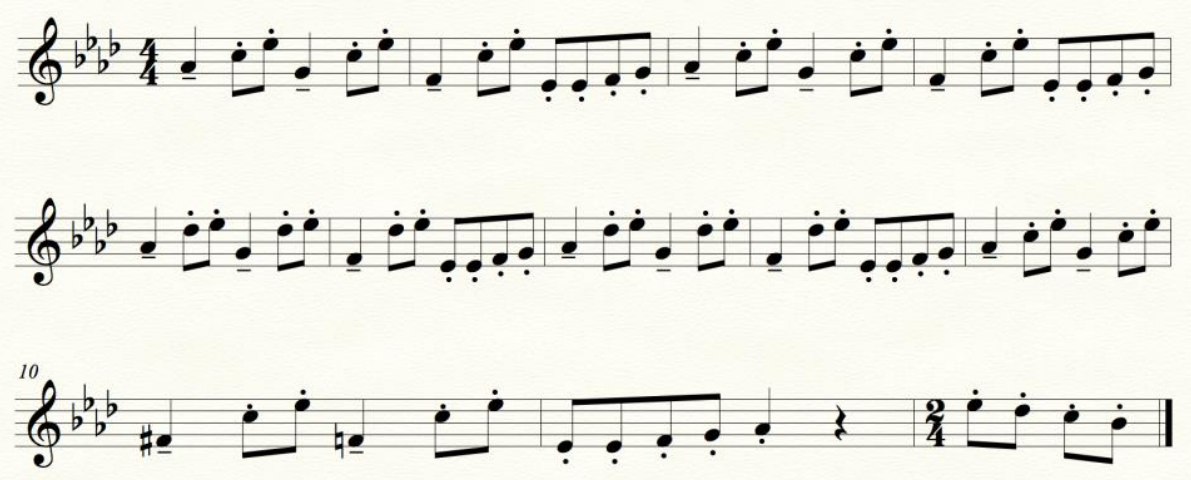

Electric guitar motif in "Ge mej mera köttbullar"

As I have pointed out, the stories about Madicken and her little sister take place in Sweden during World War I. The connection between the lyrics and the musical environment would be remote if not for the energy invested in the vocal performances. On the one hand, as already mentioned, the sparse arrangement leaves a relatively open space for the voices to shine through. On the other hand, on a more detailed level, the aesthetic, especially evident in the electric guitar motif, supports the energetic vocal performances, suggesting some form of youth-like pop-rock energy found in earlier Beatles recordings 
such as "I Feel Fine" (1964). Juxtaposed with the lyrics, which mainly address the issue of preferring pancakes and meatballs to fish pudding, one could argue that the environment is active in supporting Madicken and Lisabet's passion for this particular case. Within this framework, and considering the rather downplayed use of drums, bass, and piano, the sonic qualities of the electric guitar become a sonic marker - that is, a narrative strategy for propelling the energy of this particular song.

As with Madicken, Pinky is a character in the fictional Captain Sabertooth (Kaptein Sabeltann), a commercially successful children's series ${ }^{5}$ with an overarching narrative about pirates, treasure hunting, and the mysterious, dangerous, and powerful Captain Sabertooth. In "Pinkys sang," we are introduced to a young orphan nicknamed Pinky, whose biggest dream is to become a pirate on Captain Sabertooth's ship. In this song, he has actually achieved his goal, and he has become the youngest pirate of the seven seas:

Jeg er Pinky.

Det kalles jeg om bord.

Selv om jeg er liten

vil jeg gjerne være stor.

Jeg er Pinky.

Pinky er mitt navn.

Til vanlig er jeg sjørøver

men nå er vi i havn.

\section{I am Pinky}

That's what I'm called on board

Even though I'm small

I would love to be big

I am Pinky

Pinky is my name

Usually, I'm a pirate

But now we are ashore

While "Ge mej mera köttbullar" centers on three verses over a characteristic ostinato, where semitone upward modulation into the third verse provides the main dynamic lift, "Pinkys sang" is more or less spun around the form of a standard pop song (intro-verse-chorus-verse-chorus-solo-verse-chorus). Thus, the Sabertooth narrative might seem to represent a commercialization of children's culture. In the various existing recordings of this song, at least three different actors sing the voice of Pinky [Martin Usterud (Formoe,1991), Ole Alfsen (Formoe, 2005) and Ole Tobias Tveit (Formoe, 2010)]. Although the musical arrangement and production are the same in each version, these are very different singers. I would suggest, however, that since they are all acting as Pinky, the meaning of the different versions is affected less by the vocal performances than by the use of dialect that suggests local belonging. While the main adult characters in the series (Captain Sabertooth and Langemann, for example) often tend to speak so-called Eastern Norwegian, ${ }^{6}$ the children - in the TV series as well as in the annual summer shows held in Dyreparken - speak and sing in the Kristiansand dialect. Situated and created in

\footnotetext{
${ }^{5}$ I call Captain Sabertooth (Kaptein Sabeltann) a series here. It might be just as fruitful to refer to it as a universe. Originally created by Terje Formoe in 1989 as a theatre play in Kristiansand Dyrepark, the concept has resulted in a wide array of spin-off products such as movies, books, games, and a whole world in Dyreparken. There is also a new, spectacular show every summer, contributing to making Captain Sabertooth one of the most popular children's concepts in Norway.

${ }^{6}$ Eastern Norwegian dialect is often associated with the areas around Oslo, in a Norwegian context. Being closest to the written language (bokmål), it is even identified as a non-dialect.
} 
Dyreparken in Kristiansand, this use of local dialect authenticates the Captain Sabertooth show by providing it with a strong local connection.

After a short introduction played on a marching drum, acoustic guitar(s), accordion, and bass are added. A short melodic theme is then delivered by a synthesizer sound resembling a tin whistle (Figure 2).

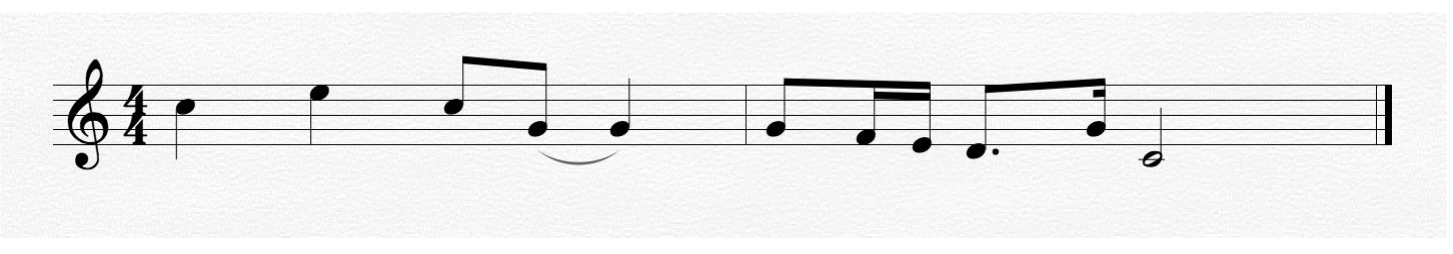

Tin whistle theme from "Pinkys sang"

In combination, these musical elements suggest that Irish folk music might have been a source of inspiration. Here lies a potential paradox: the sounds of these instruments are not necessarily connected to life at sea. In fact, they could easily hint at other music that has nothing to do with sea life. At the same time, the timbral qualities of accordion and flute, in particular, along with the rhythmic phrasings and the tonal landscape in which they are put to life, carry a potential for being interpreted in this way within the context of a narrative for children about pirates.

\section{Sonic Markers in Narratives of the "Real"}

In contrast to the former two musical examples within a fictional framework, Marcus and Martinus' song, "Slalom," from their album Hei, represents the second narrative strategy suggested in this article: narratives of the "real." In this song, sonic markers might contribute to authenticating Markus and Martinus by bridging a gap between music for children and music for adolescents. With "Slalom," as with more famous singles such as "Elektrisk," "Plystre på deg," and "Na Na Na," Marcus and Martinus entered a new realm of the pop music industry. They became superstars, at least in Norway. Just before Christmas in 2015, their debut album Hei had sold to platinum, and they sold out two shows at Oslo Spektrum, one of Norway's largest indoor arenas. Considering that their latest single "Girls" has English lyrics, "Slalom" could be regarded as an early step toward international promotion.

Children in the pop music industry are hardly new phenomena. Michael Jackson, for example, entered the commercial pop circus with his family band, The Jackson 5, at the age of 11 with "I Want You Back" (1969). A couple of years later, Jimmy Osmond, riding high on his older brothers' immense success with The Osmonds, became the youngest artist to reach number one on the UK Singles Chart with "Long Haired Lover from Liverpool" (1972). He was only nine years old at the time. In these cases, along with a range of others, age has undoubtedly played a major role for launching upcoming pop stars, but not in promoting music for a child audience. Rather, as Jacqueline Warwick (2012) noted, Jackson's appeal as a child star was by and large connected to his ability to play on codes more frequently associated with adults:

Michael Jackson's child star persona - presented as part of a wholesome, loving family, with loving older brothers indulging his cheekiness - was unmistakably urban, confident and precocious, with comedy based on the juxtaposition of his tiny body and his cocky attempts at manly dignity and sexual power. (p. 247) 
Warwick further ascribed Jackson's success as a child star to the tension that arises in the juxtaposition of a child who behaves like a grownup.

However, quite unlike Michael Jackson and Jimmy Osmond, Marcus and Martinus started their career by being promoted as child stars for children. Specifically, their success started when they won the MGP Junior in 2012 with their song "To dråper vann" (Various Artists, 2012). With this song, they entered the realm of commercial pop music as themselves - as twins who, aside from sharing pretty much the same looks and a number of interests, also happened to have significant musical talent. Born in 2002, Marcus and Martinus now teeter on the verge of adolescence. ${ }^{7}$ Yet, they still receive a massive response from children as young as three and four years of age. To what extent, then, do lyrics and vocal performance play a part in this particular narrative? Consider, for example, the chorus from their 2015 single, "Slalom":

Kjører slalom

Helt til sola går ned

Finn en verden

Under snøhvite tre

Vi kjører slalom

Og e kan smile og le

For ned i bakken

Står du og venter på me

Vi kjører

å—åoåå

vi kjører slalom

Å—åoåå

vi kjører slalom
Running slalom

Until the sun sets

Find a world

Under snow white trees

We're running slalom

And I can smile and laugh

Because just down the hill

You are waiting for me

We're running

A-aoaa

We're running slalom

A-aoaa

We're running slalom

In isolation, these lyrics deal with activities that one would consider reasonable for children to engage with in Norway. In this particular song, however, running slalom until the sun goes down, with big smiles on their faces, represents a contextual framework for a love story between two adolescents. Lyrically, the rhymes are kept quite simplistic, and the statement "Vi kjører slalom [We're running

\footnotetext{
${ }^{7}$ Marcus and Martinus won the Norwegian Grammy (Spellemannsprisen) for best artist (Årets spellemann) in
} 2016. 
slalom]" is intercut with catchy, easy-to-sing-along "å-åoåå" phrases. For listeners familiar with the Norwegian language, it should also be evident that Marcus and Martinus, like Madicken and Pinky, are singing in their own dialect. They were born in Elverum but raised in a small town called Trofors in Nordland, from which they primarily derive their vernacular. Endings such as "e," "me," and "de" instead of "jeg," "meg," and "deg" are examples of this.

Singing in one's own dialect signifies local belonging and can also contribute to producing what Moore (2002) has labeled first-person authenticity. This, Moore claimed, "arises when an originator (composer, performer) succeeds in conveying the impression that his/her utterance is one of integrity, that it represents an attempt to communicate in an unmediated form with an audience" (p. 214). I would argue that authentication takes place on a different basis in the three examples. Madicken and Lisabet, for example, sing in their own Stockholm dialect, ${ }^{8}$ even though they apparently live in a small town in Sweden, probably closer to Vimmerby, Lindgren's birthplace. The qualified suggestion that Madicken was modeled on Lindgren's childhood friend, Anne-Marie (Edström, 1997), indicates that. With regard to Pinky, the dialect seems to have been connected strongly to a sense of local belonging to Kristiansand for the whole show. During the many years Captain Sabertooth has been performed at Dyreparken, and also in the TV series, different boys from the Kristiansand area have played Pinky. Without exception, they have all kept their local dialect.

Marcus and Martinus are continuously promoted as "being themselves," a strategy in which their dialect arguably plays a key role. As Marcus says in an interview with the Norwegian state broadcasting company (NRK), "When we go on stage, we want our own style. We don't want to copy anyone. We are just ourselves, and we do what we want to do (Eriksen, 2015 [my translation]). Their dialect plays an authenticating role in assuring fans that they are nothing but themselves. In line with this, I would argue that whether or not a performance comes across as mediated is largely contingent on acquired listening experience and the listener's ability to identify various forms of mediation. Effects such as compressor, delay, or reverb require some form of experience with such tools to be able to recognize them. A younger audience, then, probably would not interpret such effects as markers of mediation, whereas representatives of the older generation may experience songs such as "Slalom" as being overproduced. My point here is that whether experienced as non-mediated or overproduced, the musical environment affects the perceived meaning of the song in question.

Turning to aspects of production in this song, several musical moments hinge upon markers of contemporary pop production. The sequenced synthesizer motif in the introduction (Figure 3) provides one example.

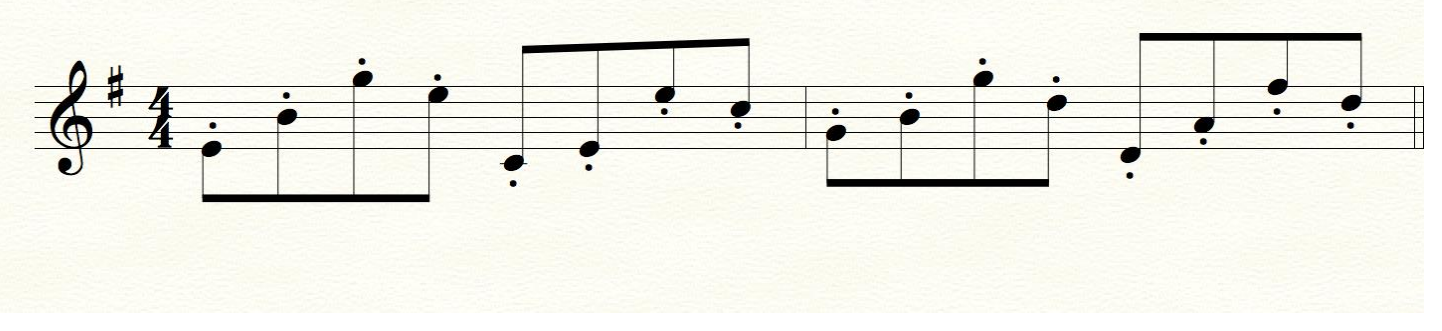

Introductory theme from "Slalom"

\footnotetext{
${ }^{8}$ Thanks to my colleague and friend, Petter Winroth, for pointing this out to me.
} 
Short staccato notes played on a synthesizer, with sharp attack and an added digital reverberation, connote contemporary electronic pop music from the beginning of the song. Although the theme in itself is moved more to the background for the benefit of a piano that forms the basic accompaniment in the choruses, the timbral, tonal, and rhythmic information still immediately help to situate the song within the realm of contemporary pop.

Besides being molded around a four-on-the-floor beat, another moment that strengthens the impression of contemporary pop production is the buildup into the choruses. This starts with the first verse, gradually building from acoustic guitars, bass, and snare drum to more complex drumming and added piano. As the chorus comes in, the guitars and drums are suddenly removed in a so-called breakdown, leaving us with only vocals and piano. After four bars, the snare drum reenters, first on quarter notes for two bars and then on 8 notes for one bar, and it gradually intensifies into 32 notes. Kicking in with full force on the last part of the chorus, at the aforementioned "å-åoåå" line, this moment represents a classic buildup in contemporary electronic dance music. From this moment, the lyrics are easy to learn and sing, even for younger children who do not understand the meaning of the words.

This is not to say that full appreciation of my earlier examples, "Ge mej mera köttbullar" (Lindgren, 2003) and "Pinkys sang," (Formoe, 2006) requires an understanding of the meaning of the lyrics. Rather, the musical environment also conveys a part of the narrative in these examples. Yet the context of each example is somewhat different. Whereas Madicken and Pinky are characters in fictional narratives, with the music primarily used to underline a particular feeling or sensibility within these narrative frameworks, Markus and Martinus are real. Their success as artists depends on us - their audiencebelieving in them as authentic. In this way, the fact that a broad age range can enjoy the music even without fully grasping the meaning of the lyrics makes them available also to a younger audience. Taken together, these factors potentially downplay the meaning of the lyrical content, especially for the youngest audience, allowing for an overall catchiness that appeals to both the 15 -year-old and the 4year-old.

\section{Toward Sonic Youthification of Childhood?}

To what extent, then, could we say that sonic markers contribute to a gradually increasing youthification of children's music? Does musical sound play a role in this growing trend? In this article, I have argued that this might be the case, illustrating how sonic markers support two narrative strategies: (a) the fictional narrative and (b) the narrative of the real. If we accept that the electric guitar in "Ge mej mera köttbullar" evokes markers of 1960s pop aesthetics and thus supports the energetic delivery of the lyrics, we can argue that the environment has a significant effect on the meaning of the song within the context of this fictional narrative. Similarly, in "PinkysSang," the sonic hint at Irish folk music, with downplayed shanty connotations, plays a role in contextualizing the protagonist. The accordion and tin whistle still carry strong connotations of life at sea. Thus, within the framework of this particular fictional narrative, they become authenticating sonic markers of seamanship and even piracy at sea. As I have pointed out, there is not necessarily a link between the instrumentation and piracy as such. It is through this particular context, within the fictional narrative of a boy's experience as the youngest pirate in the world, that the sonic potential - that is, the cultural codification of the instrumentation — can be read as sonic markers with a narrative purpose. In both of these examples, the sonic environments undoubtedly strongly support the protagonists in conveying the lyrical content in a convincing manner. At the same time, these examples would only to a limited extent represent a gradual youthification of children's music. 
Regarding the narrative of the real, however, I have shown how Marcus and Martinus' music can be said to represent a growing tendency toward the tween music industry in a Scandinavian context. For obvious reasons, their music and authorship are promoted to a tween audience, whereas the two examples from fictional narratives play a role in contextualizing certain characters in series for children. In the case of Marcus and Martinus, with both "Slalom" and the other singles from the same record serving to support the argument, I argue that their music is targeted at a commercial pop market in terms of sound production. In addition, as I have suggested, an important factor in Marcus and Martinus' authentication comes from their singing in a modified dialect. Although this last point perhaps has the strongest appeal among an adult audience, it is also the most convincing way for the artists to convey their utterance. In this particular context, it is relevant to speak not merely about a youthification of the performers but also about a youthification of the child audience (tweens).

In sum, then, the effects of the sonic markers - that we as listeners can read different narrative structures into the musical codes - are based on people's (children as well as adults) ability to associate musical sounds with narratives, whether fictional or authentic. This mechanism, in turn, attests to the assumption that sonic markers can contribute to the youthification of childhood. In view of the production aesthetics in these three songs, I would argue that all three examples use cultural codifications of sound that become sonic markers with a narrative purpose in their particular contexts.

\section{Author presentation}

Eirik Askerøi is an associate professor in popular music at Inland Norway University of Applied Sciences. His research interests include production aesthetics, popular music, cultural theory, and discursive analysis. He has contributed to publications with Routledge and Intellect Books, and to the international journal Popular Music. His works have been on Morrissey, Johnny Cash, and Beck, as well as on teaching studio production. Besides his academic activities, he works as a professional musician and, until recently, has been co-managing a recording studio (Parachute Studio) in the center of Oslo, Norway.

\section{References}

Askerøi, E. (2013). Reading pop production: Sonic markers and musical identity (Doctoral dissertation). University of Agder, Kristiansand.

Bickford, T. (2012). The new "tween" music industry: The Disney Channel, Kidz Bop and an emerging childhood counterpublic. Popular Music, 31(3), 417-436.

Bore, R. R. (Ed.) (2005). Hundre års ensomhet? Norge og Sverige 1905-2005. Oslo-Kongsvinger: Statistisk Sentralbyrå.

Dyndahl, P., \& Vestad, I. L. (2017). Decades of Recorded Music for Children: Norwegian Children's Phonograms from World War II to the Present. InFormation - Nordic Journal of Art and Research, 6(2). http://www.artandresearch.info/

Edström, V. (1997). Astrid Lindgren: En studie av forfatterskapet. (A.-M. Bjorvand, Trans.). Oslo: Damm. (Original work published 1992)

Eriksen, D. (2015). Et intervju med to norske superstjerner. Retrieved from https://www.nrk.no/kultur/et-intervju-med-to-norske-superstjerner-1.12719356.

Formoe, T. (1991). Pinkys sang. [Recorded by Morten Usterud]. On Kaptein Sabeltann og Skatten $i$ Kjuttaviga. [Cassette]. Oslo: Grappa.

Formoe, T. (2006). Pinkys sang. [Recorded by Ole Alfsen]. On Hiv O’hoi (Kaptein Sabeltanns Favoritter. [Spotify]. Oslo: Terje Formoe Records. 
Formoe, T. (2010). Pinkys sang. [Recorded by Ole Tobias Tveit]. On Kaptein Sabeltann og Grusomme Gabriels Skatt. [Spotify]. Oslo: Terje Formoe Records.

Hawkins, S. (2009). The British pop dandy: Masculinity, popular music and culture. Farnham: Ashgate.

Latham, R. (2002). Consuming youth: Vampires, cyborgs, and the culture of consumption. Chicago \& London: University of Chicago Press.

Lindgren, A. (2003). Ge mej mera köttbullar. [Recorded by Johanna Liljendahl and Liv Asterlund]. On Madicken på Junibacken. [Spotify]. Stockholm: Bonnier Music Sweden.

MacFarlan, T. (2015). March of the millennials: How neighborhoods are being "youthified" by hipsters rather than gentrified. The Daily Mail. Retrieved from http://www.dailymail.co.uk/news/article-2942340/Neighborhoods-youthified-gentrifiedmillennials-in.html.

Marcus \& Martinus. (2015). Slalom. On Hei. [Spotify]. Oslo: Sony Music Entertainment.

Moore, A. (2002). Authenticity as authentication. Popular Music, 21(2), 209-223.

Moore, A. F. (2012). Song means: Analysing and interpreting recorded popular song. Farnham: Ashgate.

Prøysen, A. (1993). Lillebror's Vise, Blåbærturen and Soltrall. [Recorded by Alf Prøysen]. On Original Prøysen 4: Hompetitten, 42 Barneviser (1946-57). [Spotify]. Oslo: Kirkelig Kulturverksted.

Ruud, E. (1983). Musikken—vårt nye rusmiddel? Om oppdragelse til og gjennom musikk i dagens samfunn [Music-our new drug? On upbringing to and through music in today's society]. Oslo: Norsk Musikforlag.

The Jackson 5. (1969). I want you back [Recorded by The Jackson 5]. On Diana Ross presents The Jackson 5. [Spotify]. Detroit: Motown Records.

Toynbee, J. (2000). Making popular music: Musicians, creativity and institutions. London: Arnold.

Tønnesen, E.S. (2015). Alf Prøysen som radiokunstner for barn. In H. K. Rustad \& A. Skaret (Eds.), Alf Prøysen, kunsten og mediene (pp. 91-115). Oslo: Novus.

Various Artists, (2012). To dråper vann. [Recorded by Marcus \& Martinus] On MGPjr 2012. [Spotify]. Oslo: Parlophone Music Norway.

Vestad, I. L. (2015a). Barnemusikk som et transdisiplinært emne: Om selvforståelse, musikkbegrep og affordanse som overskridende forskningsverktøy. Barn, 3(4), 49-63.

Vestad, I. L. (2015b). "Det aller største mor vet om . . .": Om å gi videre et levd liv med musikk og å formidle for lite. Information, 4(3), 37-49.

Warwick, J. (2012). "You can't win, child, but you can't get out of the game": Michael Jackson's transition from child star to superstar. Popular Music and Society, 35(2), 241-259. 